\title{
Evaluation of deep geothermal exploration drillings in the crystalline basement of the Fennoscandian Shield Border Zone in south Sweden
}

\author{
Jan-Erik Rosberg ${ }^{1 *}\left(\mathbb{D}\right.$ and Mikael Erlström ${ }^{2,3}$
}

\author{
*Correspondence: \\ jan-erik.rosberg@tg.lth.se \\ ${ }^{1}$ Engineering Geology, \\ Faculty of Engineering, Lund \\ University, Box 118, 221 \\ 00 Lund, Sweden \\ Full list of author information \\ is available at the end of the \\ article
}

\begin{abstract}
The 3.1- and 3.7-km-deep FFC-1 and DGE-1 geothermal explorations wells drilled into the Precambrian crystalline basement on the southern margin of the Fennoscandian Shield are evaluated regarding experiences from drilling, geological conditions, and thermal properties. Both wells penetrate an approximately 2-km-thick succession of sedimentary strata before entering the crystalline basement, dominated by orthogneiss, metabasite and amphibolite of the (1.1-0.9 Ga) Eastern Interior Sveconorwegian Province. The upper c. $400 \mathrm{~m}$ of the basement is in FFC-1 severely fractured and water-bearing which disqualified the use of percussion air drilling and conventional rotary drilling was, therefore, performed for the rest of the borehole. The evaluation of the rotary drillings in FFC-1 and DGE-1 showed that the average bit life was very similar, $62 \mathrm{~m}$ and $68 \mathrm{~m}$, respectively. Similarly, the average ROP varied between 2 and $4 \mathrm{~m} / \mathrm{h}$ without any preferences regarding bit-type (PDC or TCI) or geology. A bottomhole temperature of $84.1^{\circ} \mathrm{C}$ was measured in FFC-1 borehole with gradients varying between 17.4 and $23.5^{\circ} \mathrm{C} / \mathrm{km}$ for the main part of the borehole. The calculated heat flow varies between 51 and $66 \mathrm{~mW} / \mathrm{m}^{2}$ and the average heat production is $3.0 \mu \mathrm{W} / \mathrm{m}^{3}$. The basement in FFC-1 is, overall, depleted in uranium and thorium in comparison to DGE-1 where the heat productivity is overall higher with an average of $5.8 \mu \mathrm{W} / \mathrm{m}^{3}$. The spatial distribution of fractures was successfully mapped using borehole imaging logs in FFC-1 and shows a dominance of $\mathrm{N}-\mathrm{S}$ oriented open fractures, a fracture frequency varying between 0.85 and $2.49 \mathrm{frac} / \mathrm{m}$ and a fracture volumetric density between 1.68 and $3.39 \mathrm{~m}^{2} / \mathrm{m}^{3}$. The evaluation of the two boreholes provides insight and new empirical data on the thermal properties and fracturing of the concealed crystalline basement in the Fennoscandian Shield Border Zone that, previously, had only been assessed by assumptions and modelling. The outcome of the drilling operation has also provided insight regarding the drilling performance in the basement and statistical data on various drill bits used. The knowledge gained is important in feasibility studies of deep geothermal projects in the crystalline basement in south Sweden.
\end{abstract}

Keywords: FFC-1, DGE-1, Skåne, Drilling operation and performance, Geophysical logging, Sveconorwegian, Thermal properties, Fracturing 


\section{Introduction}

Enhanced Geothermal Systems (EGS) are defined as geothermal reservoirs that are created to be able to extract commercial amounts of heat from tight sedimentary formations or crystalline basement (Tester et al. 2006). Already in the 1970s research with hot dry rock projects as precursors to the EGS concept started (e.g., Armstead and Tester 1987; Brown 2009). Numerous EGS projects have since then been performed mainly in relatively hot crustal regions from which knowledge has and is developed regarding establishing deep geothermal reservoirs in tight rock. Recent examples are the FORGE project in Utah (Allis et al. 2016) and the United Downs Deep Geothermal Power hot granitic rock project in Cornwall UK (Ledingham et al. 2019). On the contrary, EGS feasibility studies in colder stable crustal regions, such as the Fennoscandian Shield, are sparse. The concept of creating a deep EGS in relatively cold crust for direct heat exchange is challenging but will, if successful, enable the use of geothermal heat in areas which, so far, have been disqualified for high-enthalpy geothermal systems. However, knowledge on the EGS-related properties of the crystalline bedrock at greater depth in these areas and in Sweden is constrained and every new deep drilling project as the ones presented here provide invaluable new information and knowledge.

In 2002-2003 Lund Energy AB (today Kraftringen AB) and the Department of Engineering Geology at the Lund University performed a geothermal exploration drilling project in which the DGE-1 well was drilled. The aim of the project was to find hot water in fractured crystalline bedrock associated with the Romeleåsen Fault Zone on the margins of the Fennoscandian Shield in Skåne, south Sweden (Rosberg and Erlström 2019). However, the project ended after encountering less hydraulically conductive rock mass than expected.

Around 10 years after the DGE-1 project in Lund, the interest for EGS applications in the crystalline basement increased. This has primarily been driven by the St1 EGS exploration project in Espoo, Finland, which aims to build a commercial EGS at c. $6 \mathrm{~km}$ depth in the Fennoscandian crystalline bedrock (e.g., Leary et al. 2017; Kukkonen and Pentti 2021).

The St1 project in Finland triggered E.ON (a large European electric utility company) in 2016 to investigate the potential for EGS as a future sustainable heat source in the city of Malmö, Skåne, south Sweden. The drilling operation of the basement section of FFC-1 occurred in 2020 and was the result from several years of feasibility and pre-investigation studies. In 2021, Gothenburg Energy on the Swedish west coast has also (besides E.ON) started EGS investigations, including drilling of test holes to 1-2 km depth, which furthermore highlights the increasing interest in EGS in Sweden.

This increasing interest leads to the necessity to build knowledge on technical issues related to drilling, rock mass composition, geo-mechanical properties and, thermal and hydraulic conditions of the crystalline bedrock at great depths. In line with this, the aim of this study is to evaluate and compare the results from the drilling operation and measurements conducted in the crystalline basement in FFC-1 and the results from the neighbouring DGE-1 well in Lund (Rosberg and Erlström 2019). Our study evaluates the drilling performance, rock mass composition and physical properties as well as fracturing and thermal properties, which all play a significant role in assessing the bedrock prerequisites for EGS in south Sweden. 
Furthermore, since the wells are no more than c. $20 \mathrm{~km}$ apart, it is obvious that a comparison will increase their scientific value in a regional assessment of the EGS prerequisites in Skåne. A regional assessment is included in this study which provides data on geological and thermal properties of similar rock types exposed in Dalby quarry located on the Romeleåsen Ridge.

Apart from being the third and the fourth deepest well in Sweden, both DGE-1 and FFC-1 are unique sources of information since they represent the only ones this far south on the Fennoscandian Shield that give information of the crystalline basement at great depths. Only the nearly 7-km-deep drillings at Stenberg- 1 and Gravberg- 1 in the Siljan impact structure in central Sweden (see Juhlin et al. 1998) are deeper. Furthermore, there are only a few other wells that reach deeper than $1 \mathrm{~km}$ in the Fennoscandian basement, e.g., Outokumpu R-2500 in Finland (Kukkonen 2011), the deep wells OTN1-3 in Espoo Finland (Leary et al. 2017; Malin et al. 2021; Kukkonen and Pentti 2021), the Kola super deep borehole in Russia (Arshavskaya et al. 1984) and the COSC boreholes in mid-Sweden (Lorenz et al. 2015).

Rosberg and Erlström (2019) compared the thermal properties measured and evaluated from DGE-1 with the values obtained from the wells mentioned above. In the same paper, a comparison was also made with data from wells located in the upper crystalline crust, but outside the Fennoscandian Shield, such as the KTB in Germany (Emmermann and Lauterjung 1997) and the Hunt well in Canada (Majorowicz et al. 2014). These previously made comparisons will, in this paper, be updated with the new data acquired from FFC-1. In addition, comparisons are made with the 1700-m-deep borehole, KLX02, at Laxemar in Sweden (Andersson 1994) and the 1820-m-deep borehole, Bh32012, in Lake Vättern (Sundberg et al. 2016), which both are located within the Fennoscandian Shield.

Cost-efficient drilling is essential for building competitive EGS business cases, in comparison to other energy resources, especially in areas where the target depths in relatively cold shield areas approach depths of 6-7 km. In EGS projects the drilling cost represents often more than $50 \%$ of the total cost (Garabetian 2019). It is important to increase drill bit longevity and reduce the drill bit consumption for all drilling projects and, especially, for deep EGS drillings as a step to reduce the total cost. The time to replace a drill bit around, e.g., $3 \mathrm{~km}$ depth can take around $18 \mathrm{~h}$ and the daily drilling cost can be 30,000 Euros or higher (E.ON 2021). It is therefore valuable to use experience from other drilling operations in similar geological settings, which in this case is the crystalline basement, when designing the drilling program and selecting the best suited drill bits. The two drillings in Malmö and Lund provide a unique opportunity to evaluate the drilling performance in the crystalline rocks of the Fennoscandian Shield that can guide future similar drilling projects in assessing the best drilling strategy.

\section{Geological setting}

The Precambrian crystalline bedrock in the central and western parts of Skåne belongs to the Sveconorwegian Eastern interior and boundary segments of the Fennoscandian Shield (Fig. 1). The rocks are dominated by various orthogneisses with lenses and layers of amphibolite and metabasite. The protolith rocks are c. 1.74$1.66 \mathrm{Ga}$ old granitoid rocks with minor dioritoid components and c. 1.4 and $1.2 \mathrm{Ga}$ 


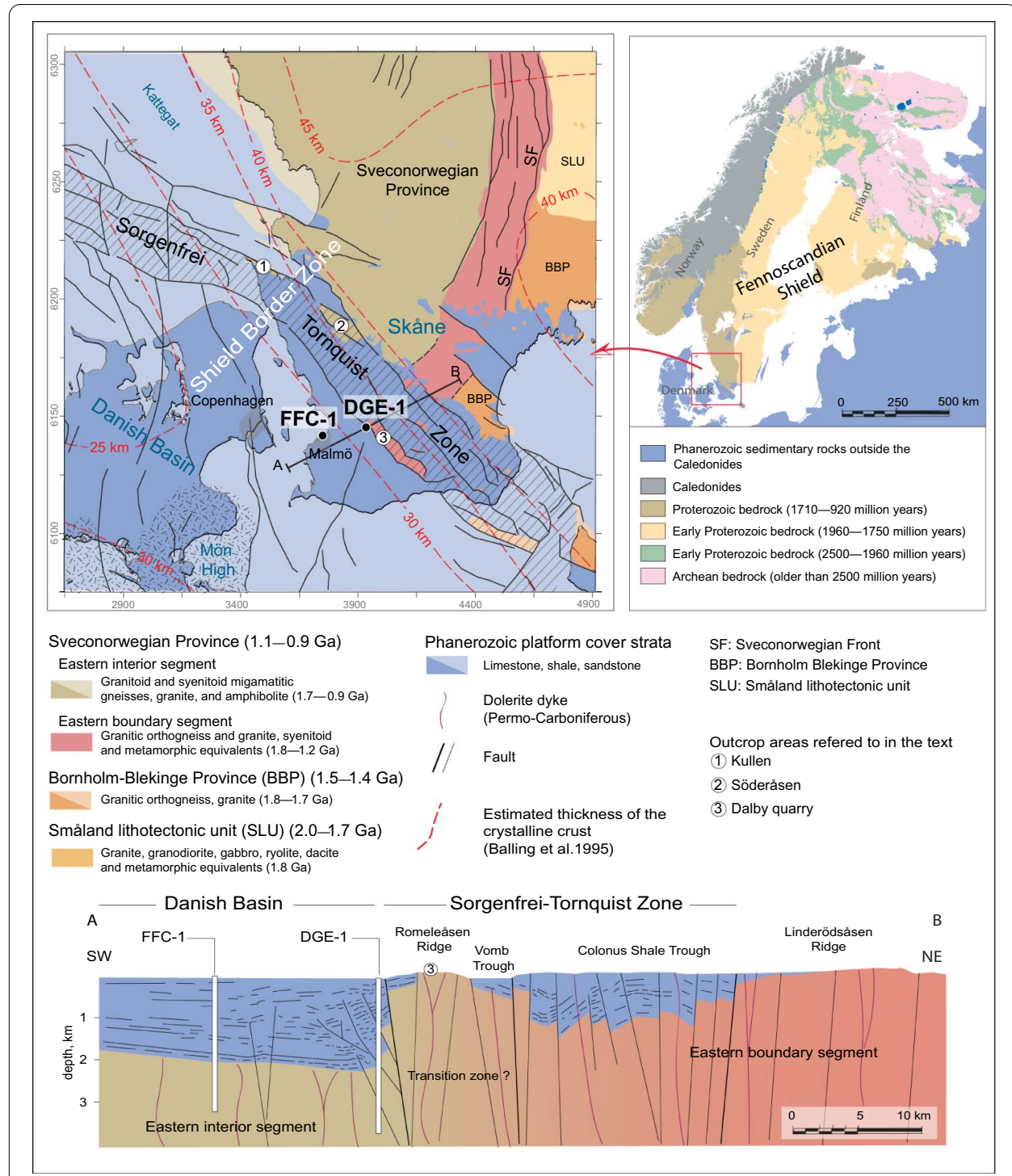

Fig. 1 Geological setting of the southwestern part of the Fennoscandian Shield and the location of the DGE-1 and FFC-1 wells

intrusive rocks, which were affected by tectonometamorphic reworking during the 1.1-0.9 Ga Sveconorwegian Orogeny (Ulmius et al. 2018; Stephens and Wahlgren 2020). Outcrops on Kullen and Söderåsen (Fig. 1) exemplify c. 1.7 Ga migmatitic gneisses, and 1.7-0.9 Ga amphibolites of the interior segment (Ulmius et al. 2018). The Eastern boundary segment, exemplified by outcrops on the Romeleåsen Ridge (e.g., Dalby quarry), and in the DGE-1 well (Rosberg and Erlström 2019), illustrates a somewhat more varied bedrock composition of 1.8-1.7 Ga orthogneiss, 1.4-1.2 Ga granite, syenite and metamorphic equivalents. In addition, the Eastern interior and the boundary segments display a high frequency of Permo-Carboniferous (c. $300 \mathrm{Ma}$ ) NW-oriented dolerite dykes, which constitute up to c. $10 \%$ of the rock mass. 
Skåne is in the outer margin of the Fennoscandian Shield Border Zone, which defines the weakened southwestern part of the Fennoscandian Shield (Erlström 2020). The zone extends from north Jutland, across Kattegat and Skåne, and includes numerous fault zones of which many are incorporated in the Sorgenfrei-Tornquist Zone (Fig. 1). The border zone portrays the transition from older stable craton areas to the northeast and younger geological provinces to the southwest and south. Towards the south and southwest the crustal thickness decreases likewise from c. 45 to $35 \mathrm{~km}$ (Thybo 1990), which contributes to an increasing heat flow and higher temperature gradients across the border zone (Balling 1995). The Fennoscandian crystalline bedrock is also successively covered by several kilometres-thick sedimentary strata to the south. Thus, the crystalline bedrock in SW Skåne is concealed by a c 2-km-thick sedimentary succession belonging to the marginal part of the Danish Basin (Sivhed et al. 1999; Erlström 2020).

Prior to the drilling of FFC-1 and DGE-1, there were only a few scattered observations on the composition of the topmost metres of the crystalline basement in SW Skane. These came primarily from oil and gas prospecting wells touching the basement beneath the thick sedimentary cover (Sivhed et al. 1999) and give only indications of a gneissdominated bedrock. The main source of neighbouring information on the crystalline bedrock comes from outcrops in north and northwest Skåne, e.g., Kullen and Söderåsen ridges, and especially on the Romeleåsen Ridge in south central Skåne (Norling and Wikman 1990; Wikman et al. 1993; Sivhed et al. 1999; Erlström et al. 2004, cf. Fig. 1). These outcrops display a tectonic pattern and structure of the crystalline basement which mirrors a complex mixture of Precambrian inherited tectonic signatures and younger tectonic events. The later correlates to the Phanerozoic break-up of the southwestern margin of the Fennoscandian Shield, including Skåne, which created a complex crustal transition zone between the stable shield and the tectonically active Phanerozoic continental Europe (Liboriussen et al. 1987; EUGENO-s Working Group 1998; Erlström et al. 1997; Thybo 1990; Erlström 2020). Rifting, strike-slip faulting, and crustal shortening, i.e., the Caledonian, Variscan and Alpine orogenic deformation phases, have resulted in a rock mass that is highly intersected by shear fractures, extensional fractures, joints, fissures, and veins. This predominantly brittle deformation is portrayed in most outcrops as heavily crushed bedrock. There is also a distinct positive Bouguer gravity anomaly in the deeper crust coinciding with the Sorgenfrei-Tornquist Zone in Skåne. This is interpreted to consist of high-density rock associated with the intrusion of magmatic dolerite dyke swarms across Skåne during the Permo-Carboniferous Variscan rift induced setting (cf. Balling 1990; Thybo 1990; Erlström 2020).

Consequently, a highly fractured rock mass, relatively thin crust, deep-seated young fault zones and magmatic bodies provide perhaps, in comparison to other areas on the Fennoscandian Shield, the best geological prerequisites for EGS in Sweden.

\section{Data base}

Our study is based on data, observations and documentation from the drilling operations, e.g., the real-time Geo-data acquisition system on rig-related properties (e.g., rate of penetration, weight on bit, rpm), well-site geological monitoring and sampling, daily drilling reports, geophysical wire-line logging, and end of well reports. Complementary analyses on cuttings from FFC-1 have included analyses of thermal 
conductivity, matrix density, chemical composition and petrographical studies on thin sections. Rock samples from the Dalby quarry on the Romeleåsen Ridge of comparable rock types have in addition been analysed regarding the thermal conductivity and density.

\section{Drilling of FFC-1}

In 2002, a 2110-m-deep well, FFC-1, was drilled and cased as a part of geothermal exploration project in Malmö, Sweden. The target was extraction of geothermal heat from the $50-60{ }^{\circ} \mathrm{C}$ warm Mesozoic sandstone reservoirs between 1600 and $2100 \mathrm{~m}$ depth. Two potential production zones, $1615-1828 \mathrm{~m}$ and $1862-2071 \mathrm{~m}$, were found and in total $315 \mathrm{~m}$ of the $95 / 8^{\prime \prime}(244 \mathrm{~mm}$ ) casing was perforated to access and test the two zones. The drilling stopped after reaching c. $18 \mathrm{~m}$ into the crystalline basement. Information about the drilling and the testing is found in DONG reports $(2003,2006)$. A schematic well completion is illustrated in Fig. 2.

In 2020, FFC-1 was re-entered, with the aim to deepen it to $4000 \mathrm{~m}$ and with the target to gather information about the crystalline basement, such as drilling performance, rock types, fractures, mechanical and thermal properties, as a step before deciding if the location is suitable for a full-scale EGS-plant or not. The deepening of FFC-1 started on June 27 and the total depth of $3133 \mathrm{~m}$ was reached on August 25. The drill rig used was HAS-Innova, type Herrenknecht Vertical (Hook load $4100 \mathrm{kN}$ ). The first planned drilling method was percussion drilling using air. To be able to use this method a $75 / 8^{\prime \prime}$ (194 $\mathrm{mm}$ ) casing was installed from surface to $2150 \mathrm{~m}$ depth. The main purpose of the casing installation was to seal the older perforated intervals and to minimize the risk for collapse of the existing casing. The new casing was cemented from the casing shoe (2142 m) to $1488 \mathrm{~m}$ depth, $127 \mathrm{~m}$ above the topmost perforations.

One of the objectives with deepening the well was to evaluate the applicability of percussion drilling using air in the crystalline basement. The used dimension of the percussion drill bit was $170 \mathrm{~mm}$ and the method was used for around $90 \mathrm{~m}$ of drilling to $2241 \mathrm{~m}$ depth. However, high-water influx disqualified continuation of this underbalanced drilling method. Hence, the subsequent drilling had to rely on conventional rotary drilling using a solids free salt polymer mud. The initial drill bit dimension was $61 / 2 \mathrm{in}$. $(165 \mathrm{~mm})$ and used to $2652 \mathrm{~m}$ depth and $61 / 8 \mathrm{in}$. (156 mm) drill bit dimension was used for the following drilling to total depth $3133 \mathrm{~m}$; see Fig. 2. The reason for changing the drill bit dimension was only due to a shortage of $61 / 2$ in. drill bits. Both tungsten carbide insert (TCI) roller cone bits and polycrystalline diamond compact (PDC) bits were used and 15 bottom hole assemblies (BHA) were tested. A downhole motor was included in seven of the these. Information about the BHAs can be found in E.ON (2021), as well as a more detailed description of the entire drilling operation.

\section{Drilling of DGE-1}

The DGE-1 drilling started on October 19, 2002 and finished on March 19, 2003. The total depth reached was $3701.8 \mathrm{~m}$, of which the lower $1756 \mathrm{~m}$ were drilled in the crystalline basement. The well is completed with casing down to $3198 \mathrm{~m}$ and has an $81 / 2^{\prime \prime}$ $(216 \mathrm{~mm})$ open main target section down to the total depth. Four different drilling methods were used: conventional mud rotary drilling, air rotary drilling, percussion drilling 


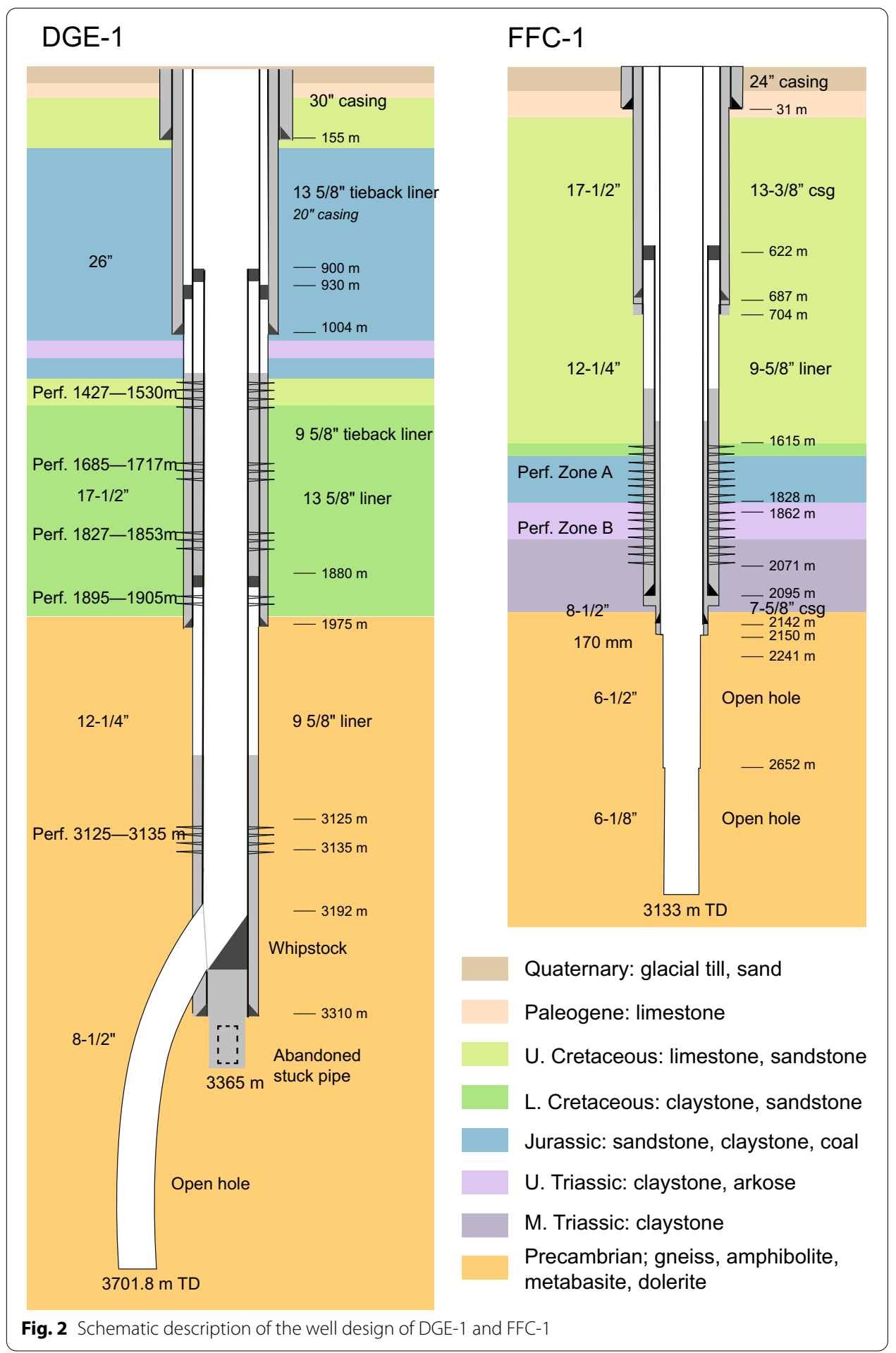

using air and percussion drilling using mud. A detailed description of the drilling can be found in the final well report (Howard-Orchard 2003) and in the publication by Rosberg and Erlström (2019). A schematic well design is illustrated in Fig. 2. 


\section{Logging campaign in FFC-1}

The Weatherford logging operation between 2138 and $3109 \mathrm{~m}$ was performed 3 months after the drilling terminated and included the following sensors: Gamma Ray, Compact Cross Dipole (CXD), Compact Spectral Gamma Ray, Compact PhotoDensity and Slim Compact Micro Imager (SCMI), with multi-arm Caliper and borehole deviation. The SCMI tool is a high-resolution resistivity tool for imaging borehole features such as fractures. The SCMI tool had a dual design which optimized the quality of the borehole resistivity image. The CXD tool is an acoustic tool that gives information on the mechanical properties and wellbore anisotropic conditions related to fracturing and in situ stresses. The Spectral Gamma Ray tool was used since it had in DGE-1 proven very useful in separating mafic rocks such as amphibolite from felsic rocks such as gneiss and granite. The spectral data on potassium (K), thorium (Th) and uranium (U), in combination with density data from the Compact PhotoDensity log, are necessary for calculating the heat productivity.

The logging operation in DGE-1 did not include any borehole imaging tools or density logging. Primarily Caliper, Sonic and Spectral Gamma Ray and a Production log (PLT) were used to characterize this well (Rosberg and Erlström 2019).

\section{Temperature survey and thermal properties}

The temperature was measured in FFC- 1 around 3 months after the drilling ended; however, there is a risk that the borehole is not fully thermally stabilized. Nevertheless, the temperature still gives indication of the temperature gradient and the heat flow in the investigated crystalline basement. The heat flow $(Q)$ is calculated using Eq. 1, where the depth compensated thermal conductivity value $\left(k_{\text {in-situ }}\right)$ is multiplied by the temperature gradient $\left(T_{\text {grad }}\right)$ :

$$
Q=k_{\text {in-situ }} \cdot T_{\text {grad }}
$$

The temperature gradient is calculated over 10-m intervals using linear regression. The correction formula (Eq. 2) presented by Chapman and Furlong (1992) is used for compensating the thermal conductivity $\left(\mathrm{k}_{0}\right)$ measured at a room temperature of $20^{\circ} \mathrm{C}$ to the in situ thermal conductivity $\left(\mathrm{k}_{\mathrm{in}-\mathrm{situ}}\right)$, which depends on the borehole temperature $(T)$ and the depth (z):

$$
k_{\text {in-situ }}=k_{0}(1+\mathrm{cz}) /(1+\mathrm{b}(T-20))
$$

Since the drilled Precambrian section in FFC-1 is dominated by orthogneiss, the same coefficient values for $\mathrm{c}$ and $\mathrm{b}$ are used in this paper, as the ones given by Chapman and Furlong (1992), i.e., $\mathrm{c}=1.5 \cdot 10^{-6} / \mathrm{m}$ and $\mathrm{b}=1.5 \cdot 10^{-3} / \mathrm{K}$, representative for granitic upper crust.

The heat production $(\mathrm{A})$ is calculated using the concentrations of the radiogenic isotopes of uranium $(\mathrm{U})$, thorium $(\mathrm{Th})$ and potassium $(\mathrm{K})$ from the spectral gamma ray log. Most of the geothermal heat generated in the crust derives from decay of these isotopes (Wollenberg and Smith 1987). Therefore, it is a common approach to use spectral gamma ray logging data for evaluating the heat production in deep boreholes in the upper crust, e.g., exemplified in Majorowicz et al. (2014), Jiang et al. (2016), and Rosberg 
and Erlström (2019). The empirical formula, see (Eq. 3), presented in Bücker and Rybach (1996) is used for calculating the heat production:

$$
A=10^{-5} \cdot \rho \cdot\left(9.52 \mathrm{U}_{\mathrm{ppm}}+2.56 \mathrm{Th}_{\mathrm{ppm}}+3.48 \mathrm{~K}_{\text {percent }}\right)
$$

The density values $(\rho)$ are obtained from the photo-density logging.

\section{Results and discussion}

\section{Drilling experiences}

The rate of penetration (ROP) acquired in FFC-1 when drilling in the crystalline basement illustrates that high penetration rates, up to $15 \mathrm{~m} / \mathrm{h}$, were obtained during the attempts with percussion drilling using air, between 2150 and 2242 m depth (Fig. 3). Cost consuming trips to inspect hammer, as well as difficulties to monitor downhole hammer function, and problems with hole cleaning due to heavily fractured rock and inflow of formation fluid led to the abandonment of the percussion drilling method. The Caliper log also verifies that the basement down to c $2500 \mathrm{~m}$ included several zones of weak and unstable rock that resulted in significant break-out and greater borehole

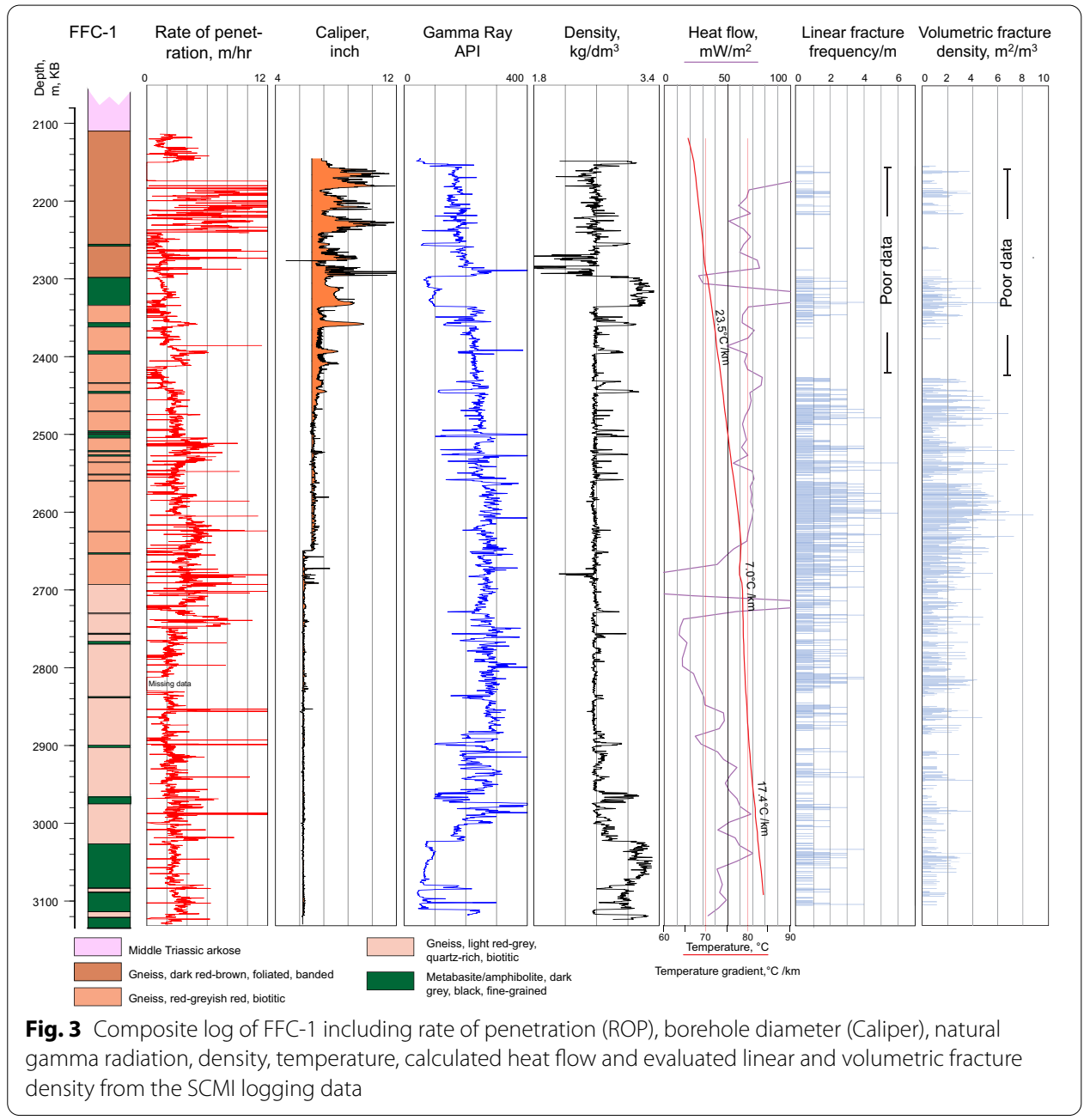


diameter (Fig. 3). These zones were also associated with inflow of water, which rendered difficulties to clean the well as well as getting the hammer to properly operate. However, it is not concluded if the method could have worked at greater depth with less fractured rock and less inflow of water.

The ROP for the conventional mud rotary drilling varied between 1 and $4 \mathrm{~m} / \mathrm{h}$, the values are similar for the ROPs acquired during the drilling of the crystalline basement in DGE-1 (Rosberg and Erlström 2019). Larger bit dimensions and initially different drilling method, air rotary, was used in the crystalline basement in that well. Cardoe et al. (2021) report average ROPs between 2.3 and $2.6 \mathrm{~m} / \mathrm{h}$ for the sections drilled with rotary techniques in the two deep wells in Espoo, Finland.

In total, 15 drill bits were used in FFC-1, seven PDC and eight TCI roller cone bits; see Fig. 4. Two of the used drill bits, one TCI roller cone and one PDC, are shown in Fig. 5. Drill bit manufacturers often use their own product names and nomenclature and to be able to compare the drill bits presented in Fig. 4, the IADC code (International Association of Drilling Contractors) is used. Information about the IADC code can be found in the IADC Drilling Manual (2000) and there are also the, so-called, IADC calculators available on the web. On average the drill bits drilled $58 \mathrm{~m}$ before being changed or $66 \mathrm{~m}$ if the two bits that only lasted for 2 and $3 \mathrm{~m}$ are excluded. Three drill bits lasted more than $100 \mathrm{~m}$ and where all used in combination with a downhole motor. The longest distance drilled with one bit was $146 \mathrm{~m}$ and it was achieved using a PDC drill bit. The operational parameters varied within the following intervals during the bit run: WOB: 2.3-10 ton, Bit RPM: $165-215$, ROP 2-6 m/h, Torque: 3-10 kNm (E.ON 2021). Three of the PDC bits also resulted in the highest average ROP obtained during the different bit runs, $3.1-3.3 \mathrm{~m} / \mathrm{h}$.

The drill bit summary from the drilling in the crystalline basement in DGE-1 is also included in Fig. 4. The drill bits used before and after the whipstock installation are

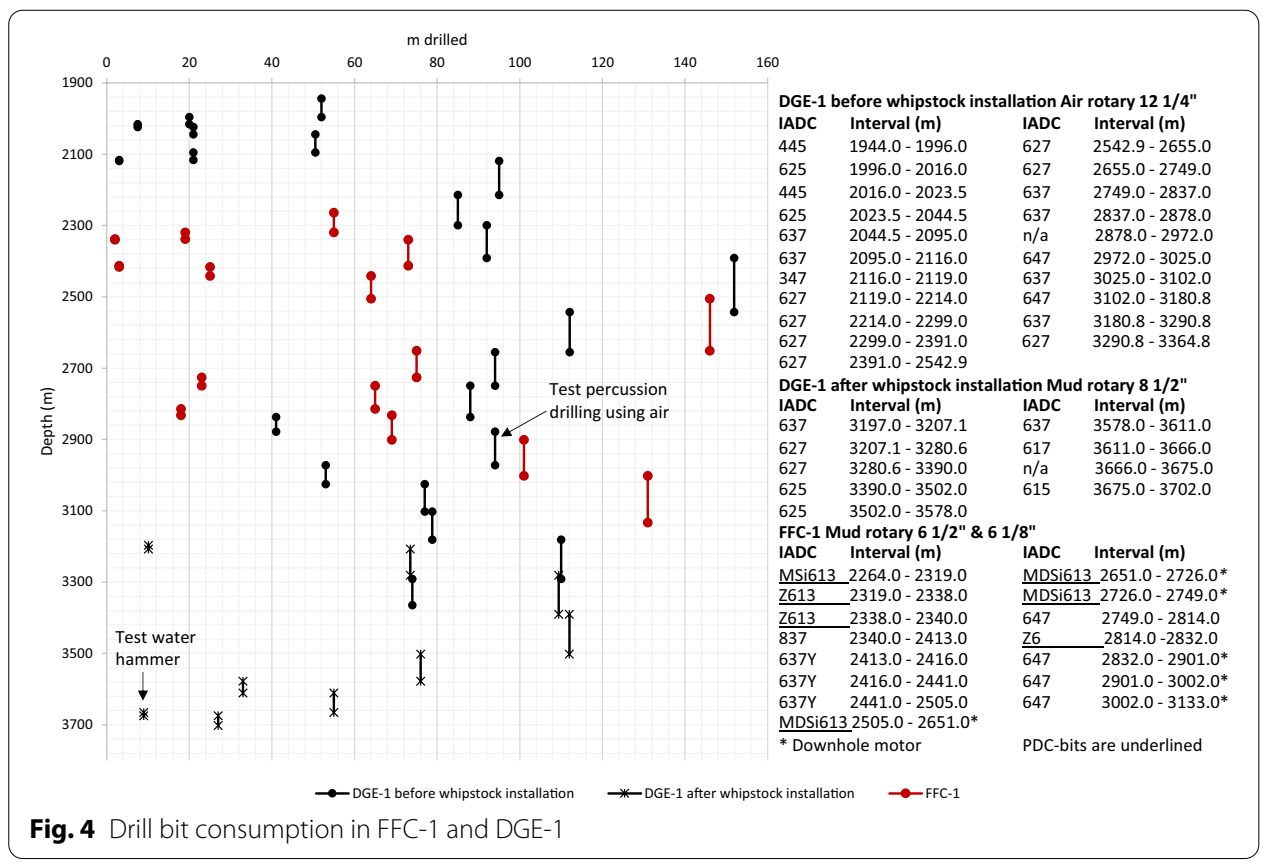




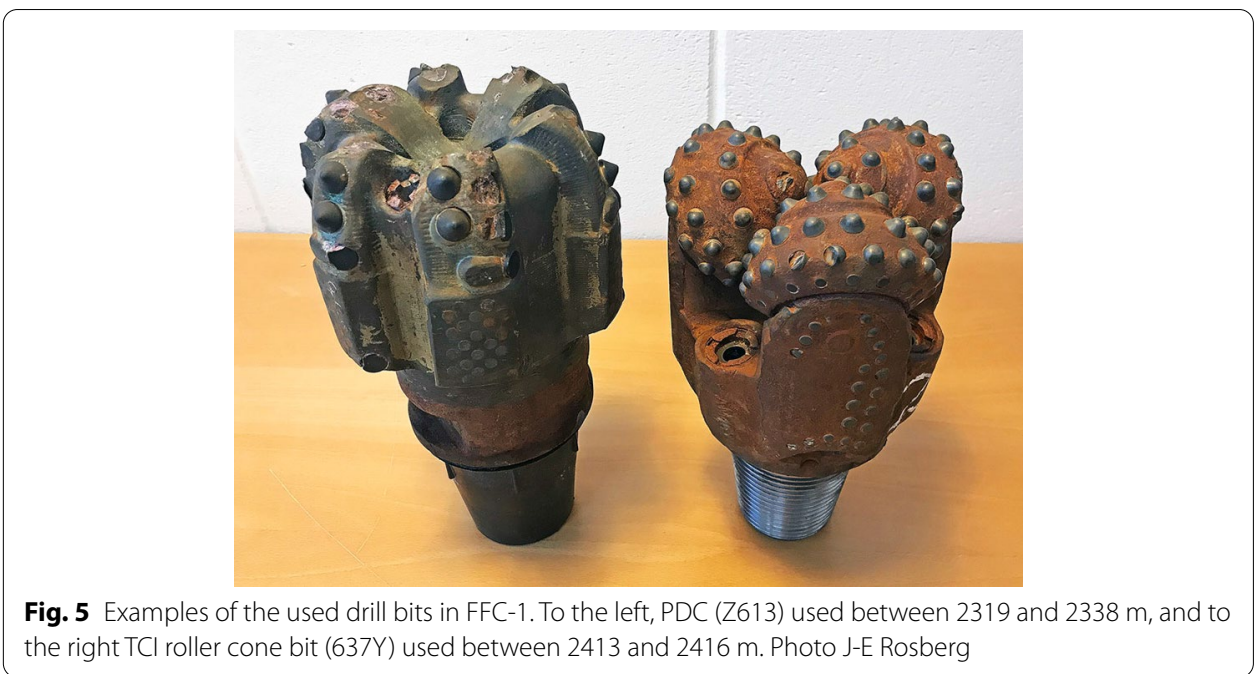

presented separately. Air rotary drilling was used before and mud rotary after whipstock installation, and in both cases larger drill bit sizes than in FFC-1 were used. Detailed information about the used drilling methods, drilling dimensions and the whipstock installation can be found in Rosberg and Erlström (2019). In total, 21 drill bits were consumed before the whipstock installation and in average the drill bits lasted for $68 \mathrm{~m}$. Three drill bits lasted more than $100 \mathrm{~m}$ and the longest distance drilled with one of the TCI roller cone bits was $152 \mathrm{~m}$. It can also be seen in Fig. 4 that there is a learning curve, after around $175 \mathrm{~m}$ drilling into the crystalline basement the metres drilled by each drill bit increased. In this case it is more likely due to experienced gain during the drilling operation than due to geological changes. In total nine drill bits were used after the whipstock installation and on average the drill bits lasted for $56 \mathrm{~m}$ or $62 \mathrm{~m}$ if the water hammer prototype bit is excluded. Two of the drill bits lasted for around $110 \mathrm{~m}$. The lessons learnt from comparing the drill bit consumption during the two deep crystalline basement drillings in Skåne are that the drill bits lasted in average between 62 and $68 \mathrm{~m}$. Quite similar results, despite different bit dimensions and drilling fluids were used. This is somewhat unexpected since a larger dimension TCI bit normally lasts longer than a smaller one, because of larger and more robust bearings. The rate of penetration is also quite similar when comparing the two drillings as well. It seems like PDC bits were a better option than TCI roller cone bits in FFC-1, but to make this evaluation more correctly information about the bottom hole assemblies (BHAs), operational parameters and the rock composition must also be included in the evaluation. It can, for example, be noted that the best bit performance was achieved using a downhole motor in the FFC-1 drilling. In this paper, the drill bit consumption in the two wells have been compared but not the drill bit performance. One way to do this is to compare the mechanical specific energy (MSE), initially presented by Teale (1965), for the different bit runs. The MSE is the ratio between the mechanical energy input from the drill rig and the responding ROP and it can also be explained as the energy required to remove a unit volume of rock. That different drill bit dimensions that were used could be considered if the MSE is calculated. 
There is room for improvements to decrease the drill bit consumption when drilling new deep wells in the Fennoscandian Shield Border Zone. Longer bit life and a lower drill bit consumption will markedly decrease the total well cost or expressed as footage cost/cost per metre. Cardoe et al. (2021) reported that the average rotary bit life in the first deep well drilled in Espoo, Finland was $69 \mathrm{~m}$, which is like the values obtained in FFC-1 and DGE-1. The same paper also describes that a special bit design was made before rotary drilling was applied in the second deep well, which increased the average bit life to $116 \mathrm{~m}$. Recently, Energy and Geoscience Institute at the University of Utah (2021) reported exceptional results for a $9145 \mathrm{ft}(2787 \mathrm{~m})$ deep well, where three 8.75" (222 mm) PDC bits were changed after drilling $332 \mathrm{~m}, 368 \mathrm{~m}$ and $376 \mathrm{~m}$, respectively, in granodiorite. The longest bit life, with almost the same dimension $8.5 \mathrm{in}$. (216 mm), of the TCI bits used in DGE-1 well was around $110 \mathrm{~m}$. Despite it being a different bit-type and used in a much younger rock, it is still at least three times less drilled in comparison to the PDC bits used in Utah.

The evaluation of the percussion drilling using air is omitted from this paper, but still one observation can be made that the drilling method cannot be applied if the water influx is high. Percussion drilling using air has been successfully used in the deep EGSdrillings in Espoo, Finland (e.g., Think Geoenergy 2019) and during the drilling of DGE-1 both air rotary drilling and the testing of percussion drilling were applied down to $3365 \mathrm{~m}$, which is described in Rosberg and Erlström (2019). The main difference if the two drillings are compared with FFC-1 is that problems with water influx are only reported from FFC-1.

\section{Bedrock composition}

The description of the cuttings (examples are shown in Fig. 6) and correlation with the Spectral Gamma Ray log (Fig. 7) reveals that the crystalline basement in FFC-1 is dominated by two rock suites. The relative distributions of the various rock types in FFC-1 are compared with DGE-1 in Table 1.

The bulk part (80.6\%) of the penetrated rock mass in FFC-1 is composed of different gneisses. These felsic rocks $\left(>70 \% \mathrm{SiO}_{2}\right)$ are dominated by quartz, feldspar, and minor amounts of minerals such as mica and hornblende. The colour varies from dark red to light red and grey. Darker red banded gneiss, i.e. with numerous concordant thin layers of meta-mafic rocks, is predominantly found in the upper part of the FFC-1 borehole down to c. $2300 \mathrm{~m}$ depth. The varieties occurring below are less foliated and relatively quartz-rich and greyish. There are also scattered thin intervals with very quartz-rich and mica-rich (muscovite) gneiss at 2630-2640 m, 2756-2686 m and 2835-2841 m.

The amphibolite/metabasite/amphibolite-gneiss rock suite represents a group of metamorphic silica-poor mafic rocks dominated by hornblende and plagioclase. The low content of potassium feldspars is also portrayed by a corresponding low potassium signature in the Spectral Gamma Ray log where these rocks occur in the borehole. These mafic rocks are characterized as fine- and medium-crystalline, mostly dark grey and black and often with a white spotted texture of light-coloured plagioclase in a matrix dominated by hornblende and biotite. The amphibolite also frequently contains minute garnet crystals. Several of these rocks can also be classified as amphibolite-gneiss since the quartz content is relatively high and they show a weak foliation. 


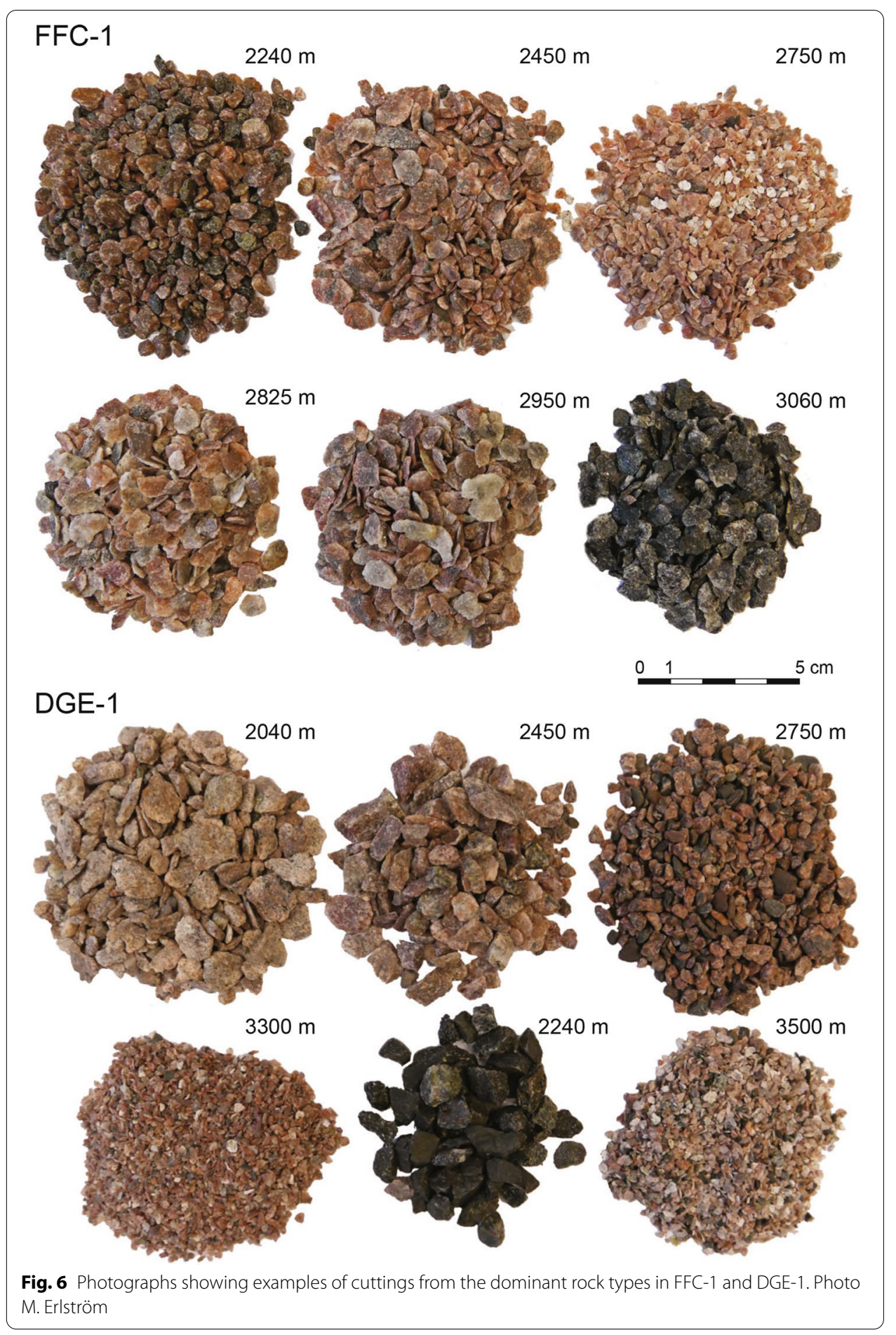

The mafic rocks constitute 19.4\% in FFC-1 and occur both as thick bodies in the upper part and lowermost part of FFC-1, and as metre-thick and thinner bands/streaks within the gneiss-dominated intervals. The density ranges between 2.9 and $3.2 \mathrm{~kg} / \mathrm{dm}^{3}$, which is significantly higher than the gneisses with densities between 2.6 and $2.7 \mathrm{~kg} / \mathrm{dm}^{3}$. This difference is also significantly pictured in the PhotoDensity log (Fig. 3), which furthermore 


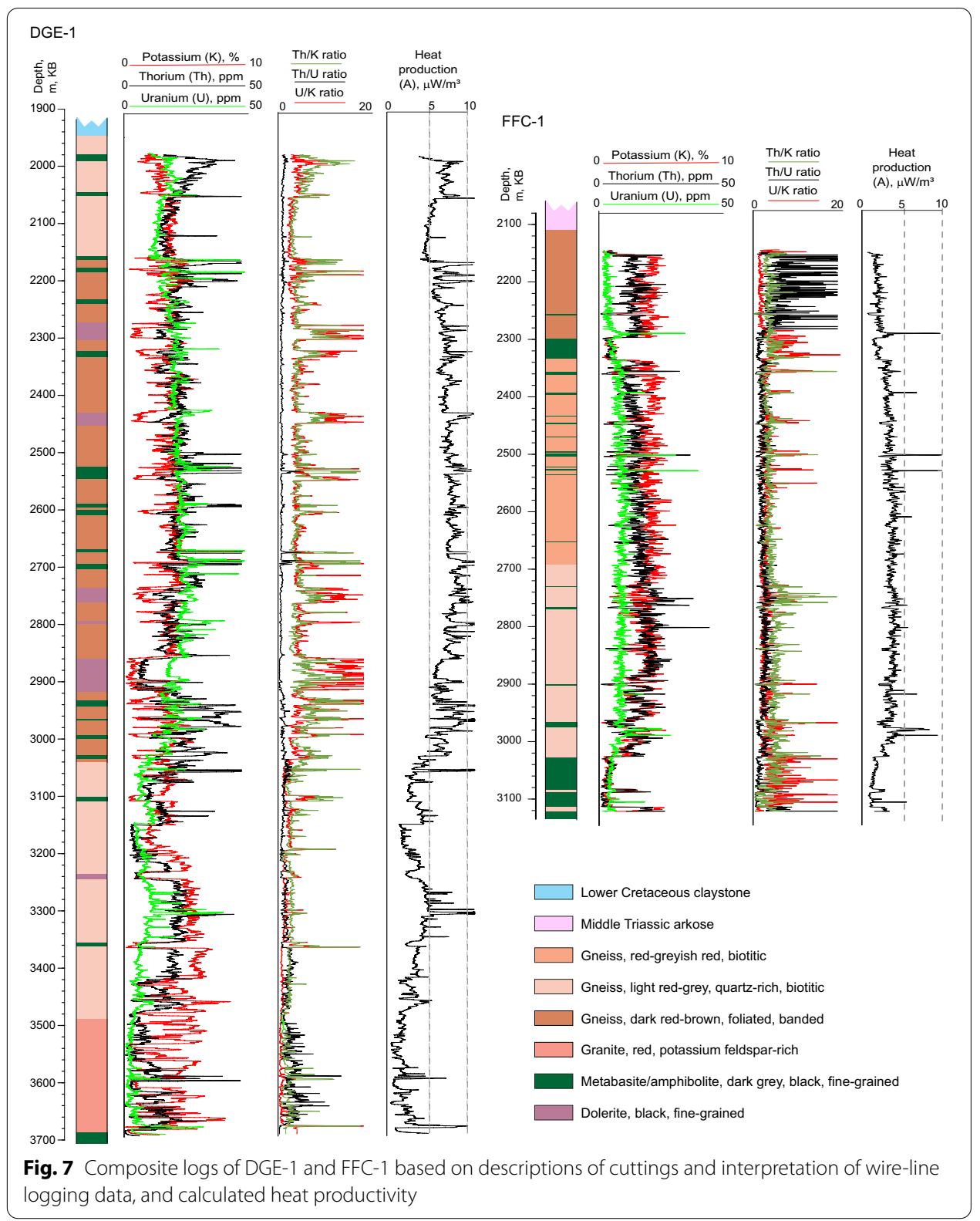

Table 1 Relative distribution of rock types in FFC-1 and DGE-1

FFC-1 relative distribution, $\%$

DGE-1 relative distribution, \%

Amphibolite, metabasite, amphibolite-gneiss 
helps to differentiate these rock types in the borehole. Larger bodies of dense mafic rocks also provide conditions for delivering strong seismic reflectors, which is verified in the older seismic data in Malmö where the thick amphibolite at the bottom of the borehole (3025-3133 m) links up to a seismic reflector (Hammar et al. 2021). Likewise, strong seismic reflectors in the basement in DGE-1 were confirmed to originate from changes in the acoustic impedance at the gneiss-amphibolite boundaries (Rosberg and Erlström 2019).

The two dominating rock suites in FFC-1 and DGE-1 correspond to the Sveconorwegian gneiss-dominated terrain in SW Sweden exemplified by the outcrop areas on the Romeleåsen Ridge and in northwest Skåne, e.g., Kullen and Söderåsen (Fig. 1).

The gneisses are quite similar in both wells. The main difference is that there is a greater proportion of dark red-brown, foliated and banded gneiss in DGE-1 and that the quartz-rich variety in FFC-1 is not identified in DGE-1.

Another notable observation is the absence of Permo-Carboniferous dolerites in FFC1. These rocks are a common part of the rock mass in DGE-1 as well on the Romeleasen Ridge and within the Sorgenfrei-Tornquist Zone in Skåne. This difference could be explained as the main phase of Variscan rifting and emplacement of NW-SE dolerite dykes in Permo-Carboniferous time was mainly within the Sorgenfrei-Tornquist Zone and not as frequent outside this zone to the southwest.

There is also a notable difference in the overall thorium and uranium content in the rock mass in FFC-1 in comparison to DGE-1 (cf. Spectral Gamma log in Fig. 7). The significantly lower values in FFC-1 are interpreted to represent the relatively U-Thdepleted rock mass in the Eastern interior Sveconorwegian segment in comparison to the eastern boundary and transition segments (data from the radiometric map of Sweden; Geological Survey of Sweden).

\section{Fracturing and structure of the rock mass}

The upper ca $500 \mathrm{~m}$ of the crystalline bedrock is found to be severely fractured in FFC1. The Caliper log shows over-sized and very poor borehole conditions (Fig. 3), which affects the quality of the geophysical logs in this section. Below $2500 \mathrm{~m}$ the fracturing is less significant to the borehole which provided good operational conditions for the CXD and the SCMI tools. The results from these gave unique and novel data on the fracturing of the rock mass at these depths. The first study of the fracturing, performed by Weatherford on commission by E.ON, shows that there is conclusive evidence of a conductive fractured zone between 2562 and $2695 \mathrm{~m}$ (Badulescu and Ciuperca 2021). The fracture volumetric density as well as the fracture frequency in this zone is significantly higher (average $3.39 \mathrm{~m}^{2} / \mathrm{m}^{3}$ and $2.49 \mathrm{frac} / \mathrm{m}$ ) than below where it is generally less than $2 \mathrm{~m}^{2} / \mathrm{m}^{3}$ and 1-2 frac/m (Fig. 3, Table 2). The fracture frequency is commonly $>4$ frac $/ \mathrm{m}$ for the most fractured part of the zone where also individual fracture apertures reach up $12 \mathrm{~mm}$ (Ciuperca et al. 2021).

A calculation of the linear fracture frequency for three main borehole intervals including the fractured zone $(2562-2695 \mathrm{~m})$ and the interval above $(2450-2522 \mathrm{~m})$ and below $(2695-3106 \mathrm{~m})$ is shown in Table 2. No values could be calculated above $2450 \mathrm{~m}$ due to poor borehole conditions. The average linear fracture frequencies in these three major 
Table 2 Calculated linear fracture frequency for three intervals in FFC-1

\begin{tabular}{lllll}
\hline Borehole depth & Interval thickness & Number of fractures & $\begin{array}{l}\text { Linear fracture } \\
\text { frequency, frac/m }\end{array}$ & $\begin{array}{l}\text { Volumetric } \\
\text { fracture density, } \\
\mathbf{m}^{2} / \mathbf{m}^{\mathbf{3}}\end{array}$ \\
\hline $2150-2450 \mathrm{~m}$ & $300 \mathrm{~m}$ & No reliable data & - & - \\
$2450-2562 \mathrm{~m}$ & $112 \mathrm{~m}$ & 181 & 1.62 & 2.67 \\
$2562-2695 \mathrm{~m}$ & $133 \mathrm{~m}$ & 329 & 2.49 & 3.39 \\
$2695-3106 \mathrm{~m}$ & $411 \mathrm{~m}$ & 353 & 0.85 & 1.68 \\
\hline
\end{tabular}

intervals range between 0.85 and $2.49 \mathrm{frac} / \mathrm{m}$ and average volumetric fracture densities between 1.68 and $3.39 \mathrm{~m}^{2} / \mathrm{m}^{3}$.

Borehole data on the spatial distribution and orientation of fractures are, besides in situ stress and hydraulic data, essential parameters to build Discrete Fracture Network (DFN) models. However, it is not a straightforward process to assess the linear fracture frequency and the volumetric fracture density in FFC-1 with respect to the feasibility of the rock mass to be hydraulically stimulated and made suitable as a geothermal reservoir. There are also few reference values on the linear fracture intensity for the Fennoscandian crystalline basement at greater depths in Sweden. Existing data come primarily from the Swedish Nuclear Fuel and Waste Management Company (SKB) borehole investigations down to c. $1000 \mathrm{~m}$ depth. Their data from boreholes in granitoid rocks at Laxemar, on the east coast of Sweden, give an open fracture frequency generally below $3 \mathrm{frac} / \mathrm{m}$ and a volumetric fracture density between 1.4 and $4.6 \mathrm{~m}^{2} / \mathrm{m}^{3}$ (La pointe et al. 2008; SKB 2009). Another reference data set comes from image-log data of the spatial distribution of fractures in the crystalline basement in the deep geothermal projects in Basel in Switzerland, Soultz-sous-Forêts in France and the Rosemanowes site in the UK. These give fracture spatial distribution signatures for depths ranging between c. 2000 and $5000 \mathrm{~m}$ which are mostly below c. 1 frac/m (Meet 2019). In addition, $<0.3 \mathrm{frac} / \mathrm{m}$ are reported between 6900 and $7135 \mathrm{~m}$ depth in the KTB deep borehole (Zimmerman et al. 2000).

Comparable reference values on the fracture volumetric density are even more scarce. A study by Rogers et al. (2015), even if this is on relative shallow rock masses, indicates that the transition from a massive rock mass to a more kinematically governed blocky rock mass occurs at c. $2-2.5 \mathrm{~m}^{2} / \mathrm{m}^{3}$.

With respect to the scarcity of data and difference in geological setting between the various reference values, it appears that the FFC-1 data fall within what is generally observed for other deep drilling projects in crystalline rocks.

The dominant strike of the SCMI-identified hydraulically conductive borehole crosscutting fractures, between 2154 and $3106 \mathrm{~m}$ is N-S. There is also a less dominant NESW strike noted. Remarkably there is no significant NW-SE strike, which is otherwise the general direction of the main faults in Skåne (Badulescu and Ciuperca 2021). The conductive fracture sets are interpreted to be open and correspond to the NW-SE strike-slip and associated N-S extension in Skåne since the Permo-Carboniferous (Bergerat et al. 2007). These initial interpretations will, however, be further scrutinized in an ongoing in-depth analysis.

Scattered iron oxide coatings on the fracture/fissure planes, are identified on the cuttings, especially for the section down to c. $2500 \mathrm{~m}$. Only few of these were noted in the 
deeper part of the borehole. Besides this, a white, soft non-calcareous clayey material is found in most samples from the gneiss-dominated intervals. XRD and chemical analysis show that it is mainly composed of feldspars, quartz and mixed-layer clay minerals with chlorite. A possible explanation is that this is low temperature alteration of feldspars, a process that is common in granitoids (Plümper and Putnis 2009; Morad et al. 2010). Noticeable is that the same type of material also occurs frequently in the DGE- 1 cuttings (Rosberg and Erlström 2019). But it still needs to be clarified how these likely hydrothermal alterations are found in the rock mass. Are they primarily found in association to fractures or are they more evenly dispersed in the rock?

There are also frequent occurrences of calcite fracture fillings in the cuttings, especially in the metabasite and amphibolite intervals. Beside these mineralizations there are also greenish undulating fracture fillings with epidote and chlorite found in the gneiss. The overall fracture fillings found in FFC-1 and DGE-1 agrees well with the fracture mineralogy in rocks from the Dalby quarry (Halling 2015).

The overall structure, foliation, banding and folding, of the bedrock in Skåne is interpreted by Ulmius et al. (2018) and by Wikman et al. (1993) to be steeper in the boundary zone and gradually more horizontal in the interior part of the Eastern segment in the Sveconorwegian Province. A dominant low angle and horizontal foliation, identified in the CXD and SCMI logs in FFC-1, fits with the overall structure of the interior part of the Eastern segment.

\section{Thermal conductivity, density, specific heat capacity and calculated in situ thermal conductivity}

Thermal conductivity, density and specific heat capacity measured on cutting samples from FFC-1 are presented in Table 3, based on analysis by Klitzsch and Ahrensmeier (2021). Results, except specific heat capacity, from similar bedrock samples from Dalby quarry on the Romeleåsen Ridge are also included in Table 3. The measured thermal conductivity values on cuttings dominated by gneiss varied between 3.85 and $3.91 \mathrm{~W} /$ $(\mathrm{mK})$ and between 2.54 and $2.59 \mathrm{~W} /(\mathrm{mK})$ for cuttings dominated by amphibolite/metabasite. In addition, the thermal conductivity was measured to $3.1 \mathrm{~W} /(\mathrm{mK})$ on cuttings dominated by foliated and banded gneiss with relatively high amount of mafic minerals The values are used in Eq. 2 for calculating the in situ thermal conductivity. The calculated average kin-situ is $3.57 \mathrm{~W} /(\mathrm{mK})$ for gneiss, $2.35 \mathrm{~W} /(\mathrm{mK})$ for amphibolite/metabasite and $2.85 \mathrm{~W} /(\mathrm{mK})$ for the banded gneiss. Based on the geological classification the thermal conductivity for the banded gneiss is later used for calculating the heat flow in the open hole section down to $2693 \mathrm{~m}$ and the higher value for the gneiss is used, below this depth. In addition, the thermal conductivity value for amphibolite/metabasite is used for intervals dominated by these rock types.

It can be seen in Table 3 that samples dominated by gneiss have a significantly higher thermal conductivity and lower density than samples dominated by amphibolite/metabasite. There is also a good agreement between density values obtained from the cuttings and the values obtained from the outcrop samples. The thermal conductivity values measured on the cuttings from FFC-1 are relatively close but higher than the values measured on the outcrop samples. 
Table 3 Compilation of thermal conductivity and density measured on cutting samples from FFC-1 and bedrock samples from Dalby quarry on the Romeleåsen Ridge

\begin{tabular}{|c|c|c|c|c|}
\hline Sample & Rock type & $\begin{array}{l}\text { Thermal } \\
\text { conductivity } \\
(\mathrm{W} / \mathrm{mK})\end{array}$ & Density (kg/dm3) & $\begin{array}{l}\text { Specific heat } \\
\text { capacity }(\mathrm{J} / \\
\text { kgK) }\end{array}$ \\
\hline FFC-1 & & & & At $30^{\circ} \mathrm{C} / 100^{\circ} \mathrm{C}$ \\
\hline $2771-2774 m^{a}$ & $\begin{array}{l}\text { Grey-light red-pinkish, quartz-rich } \\
\text { gneiss, with }<5 \% \text { of mafic rocks }\end{array}$ & $3.85 \pm 0.05$ & $2.657 \pm 0.02$ & $770 / 877$ \\
\hline $2873-2875 \mathrm{~m}^{\mathrm{a}}$ & $\begin{array}{l}\text { Grey and light red gneiss with }<10 \% \\
\text { mafic rocks }\end{array}$ & $3.95 \pm 0.03$ & $2.656 \pm 0.02$ & $765 / 865$ \\
\hline $2954-2956 \mathrm{~m}^{\mathrm{a}}$ & $\begin{array}{l}\text { Banded, grey and light red gneiss with } \\
<15 \% \text { mafic rocks }\end{array}$ & $3.10 \pm 0.03$ & $2.694 \pm 0.03$ & $770 / 877$ \\
\hline $3098-3100 \mathrm{~m}^{\mathrm{a}}$ & $\begin{array}{l}\text { Amphibolite/metabasite with }<10 \% \\
\text { amphibolite gneiss and grey-red } \\
\text { gneiss }\end{array}$ & $2.54 \pm 0.02$ & $2.994 \pm 0.03$ & $778 / 880$ \\
\hline $3104-3106 \mathrm{~m}^{\mathrm{a}}$ & $\begin{array}{l}\text { Metabasite/amphibolite gneiss }<5 \% \\
\text { grey-red gneiss }\end{array}$ & $2.59 \pm 0.02$ & $2.969 \pm 0.02$ & $776 / 879$ \\
\hline $\begin{array}{l}\text { Dalby quarry, } \\
\text { outcrop } \\
\text { sample }\end{array}$ & Red orthogneiss, fine, foliated & $3.55 \pm 0.10$ & $2.617 \pm 0.05$ & $\mathrm{n} / \mathrm{a}$ \\
\hline$-{ }^{\prime \prime} \mathrm{b}$ & -"-, massive, fine, granitic & $3.23 \pm 0.10$ & $2.622 \pm 0.05$ & $\mathrm{n} / \mathrm{a}$ \\
\hline$-{ }_{-}^{\prime \prime} \mathrm{b}$ & -"-, medium, foliated, biotitic & $3.46 \pm 0.10$ & $2.619 \pm 0.05$ & $\mathrm{n} / \mathrm{a}$ \\
\hline$-{ }^{\prime \prime} \mathrm{b}$ & Light red-grey, orthogneiss, fine & $3.58 \pm 0.10$ & $2.616 \pm 0.05$ & $\mathrm{n} / \mathrm{a}$ \\
\hline$-{ }^{\prime \prime} \mathrm{b}$ & $\begin{array}{l}\text { Red orthogneiss, medium, weakly } \\
\text { foliated }\end{array}$ & $3.52 \pm 0.10$ & $2.628 \pm 0.05$ & $\mathrm{n} / \mathrm{a}$ \\
\hline$-{ }^{\prime \prime} \mathrm{b}$ & Amphibolite & $2.38 \pm 0.10$ & $2.960 \pm 0.05$ & $\mathrm{n} / \mathrm{a}$ \\
\hline$-{ }^{\prime \prime} \mathrm{b}$ & Amphibolite & $2.16 \pm 0.10$ & $2.908 \pm 0.05$ & $\mathrm{n} / \mathrm{a}$ \\
\hline
\end{tabular}

Specific heat capacity measured at $30^{\circ} \mathrm{C}$ and $100^{\circ} \mathrm{C}$ on the cuttings from FFC-1 is also presented

${ }^{a}$ Cuttings sample analysed by Klitzsch and Ahrensmeier (2021)

${ }^{\mathrm{b}}$ Rock sample from outcrop analysed by the Geological Survey of Sweden

The specific heat capacity is an important parameter for future thermal modelling of an EGS-system. Klitzsch and Ahrensmeier (2021) measured the parameter using a calorimeter for different temperatures. Unfortunately, there are no measurements on the outcrop samples. In Table 3, the values for gneiss-dominated samples are quite like the values obtained from amphibolite/metabasite. In case the values are expressed as volumetric heat capacity, the average value for amphibolite/metabasite, 2.32 and $2.62 \mathrm{MJ} /$ $\mathrm{m}^{3} \mathrm{~K}$ is greater than the average for the gneiss-dominated samples, 2.05 and $2.33 \mathrm{MJ} /$ $\mathrm{m}^{3} \mathrm{~K}$, measured at $30{ }^{\circ} \mathrm{C}$ and $100{ }^{\circ} \mathrm{C}$, respectively. The values on the $\mathrm{FFC}-1$ samples correlate to what is known for cored boreholes in granitoid rocks at Laxemar on the west coast of Sweden, thus, further in on the Fennoscandian Shield. Sundberg et al. (2009) present heat capacities for these rocks that are between 2.16 and $2.23 \mathrm{MJ} / \mathrm{m}^{3} \mathrm{~K}$.

\section{Thermal gradient}

The bottomhole temperature in the FFC- 1 borehole is $84.1{ }^{\circ} \mathrm{C}$. In the upper part, above $2610 \mathrm{~m}$, the mean temperature gradient is $23.5^{\circ} \mathrm{C} / \mathrm{km}$ and in the lower part, below $2880 \mathrm{~m}$, the mean temperature gradient is $17.4{ }^{\circ} \mathrm{C} / \mathrm{km}$; see Fig. 3 . The zone in between seems to be thermally disturbed since the temperature gradient dropped from 23.5 to $7{ }^{\circ} \mathrm{C} / \mathrm{km}$. Below the zone the gradient increased again to $17.4{ }^{\circ} \mathrm{C} / \mathrm{km}$ (Fig. 3). The temperature anomaly is interpreted to be caused by water influx through conjugated open 
natural fractures which are identified in the logs by lower density, sonic anisotropy, changes in the brittleness index polarity, increase of the fracture volumetric density, increasing fracture aperture and the presence of Stoneley chevron up-going and downgoing reflections (Ciuperca et al. 2021). Another explanation can be that parts of this interval was acting as a loss zone during the drilling operation, meaning that the colder drilling fluid has propagated into and cooled parts of this formation interval. In comparison with the average temperature gradient, $22{ }^{\circ} \mathrm{C} / \mathrm{km}$ in the DGE-1, the upper part in FFC-1, above $2610 \mathrm{~m}$, has a $2{ }^{\circ} \mathrm{C} / \mathrm{km}$ higher gradient, but in its lower part, below $2880 \mathrm{~m}$, the gradient is $5{ }^{\circ} \mathrm{C} / \mathrm{km}$ less. The bottomhole temperature in DGE- 1 was $85.1^{\circ} \mathrm{C}$ at around $3700 \mathrm{~m}$ depth and the bottomhole temperature in FFC-1 was just $1{ }^{\circ} \mathrm{C}$ less, but it was measured at $3100 \mathrm{~m}$ depth. The extrapolated temperature in FFC-1 at $3700 \mathrm{~m}$ is $94.3{ }^{\circ} \mathrm{C}$, using the lower temperature gradient, $17^{\circ} \mathrm{C} / \mathrm{km}$. Rosberg and Erlström (2019) reported that the temperature gradient in the sedimentary succession in DGE-1 was much lower than expected and that is an explanation of the lower bottomhole temperature in DGE-1. In FFC-1, the temperature gradient in the sedimentary succession was like gradients, between 28 and $32{ }^{\circ} \mathrm{C} / \mathrm{km}$, observed in other wells located in the sedimentary succession in southwest Skåne (Erlström et al. 2018).

The lower gradient in FFC-1, $17.4{ }^{\circ} \mathrm{C} / \mathrm{km}$, is comparable with gradient measured in other deep wells in the Fennoscandian basement, such as the temperature gradient in the 6957-m-deep borehole Gravberg-1, varies between 14 and $18{ }^{\circ} \mathrm{C} / \mathrm{km}$ (Juhlin et al. 1998) and the gradient, 14 and $17{ }^{\circ} \mathrm{C} / \mathrm{km}$ in the Outokumpu R-2500 research borehole in Finland (Kukkonen et al. 2011). Similar values are also presented in Sundberg et al. (2009) from measurements down to around $1400 \mathrm{~m}$ depth in Laxemar, southeast of Sweden and gradients between 15 and $20^{\circ} \mathrm{C} / \mathrm{km}$ are obtained in the 1820 -m-deep borehole, Bh32012, in Lake Vättern, Sweden. The gradient in the deep wells OTN1-3 in Espoo Finland is also $17{ }^{\circ} \mathrm{C} / \mathrm{km}$ (Kukkonen and Pentti 2021).

The higher gradient in FFC-1, $23.5^{\circ} \mathrm{C} / \mathrm{km}$, is higher than the gradient measured in other deep wells in the Fennoscandian basement, as well as the gradient of $20{ }^{\circ} \mathrm{C} / \mathrm{km}$ that was observed for the 2500-m-deep COSC-1 borehole in the Swedish Caledonides in west central Sweden (Lorenz et al. 2015). The higher gradient in FFC-1 and the one measured in DGE-1 are more like the gradients between, 21 and $28{ }^{\circ} \mathrm{C} / \mathrm{km}$ measured in the KTB borehole in the upper central European crust in Germany (Emmermann and Lauterjung 1997) and the gradient of $20^{\circ} \mathrm{C} / \mathrm{km}$ measured in the Precambrian Canadian Shield (Majorowicz et al. 2014).

\section{Heat flow}

In the upper part of the open hole section, above $2610 \mathrm{~m}$, most of the calculated heat flow is between 60 and $70 \mathrm{~mW} / \mathrm{m}^{2}$, with an average of $66 \mathrm{~mW} / \mathrm{m}^{2}$; see Fig. 3. In the lower part of the open hole section most of the calculated heat flow varies between 40 and $60 \mathrm{~mW} / \mathrm{m}^{2}$, with an average around $51 \mathrm{~mW} / \mathrm{m}^{2}$. The zone in between seems to be thermally disturbed, which has been mentioned previously, and the calculated heat flow values for this section will most probably differ from values obtained during undisturbed thermal conditions. Therefore, those values are not considered in the further evaluation of the calculated heat flow values. The heat flow values in the upper part of FFC-1 are close to the values reported for DGE-1 (Rosberg and Erlström 2019). The heat flow 
values are also close to the values reported for other deep boreholes in the Danish Basin and the heat flow model of the Eugeno transverse for the southwest margin of the Fennoscandian Shield (EUGENO-s Working Group 1998; Balling 1995). Balling (1995) also reports that the values for the central parts of the shield are less, around 40-50 mW/ $\mathrm{m}^{2}$, which corresponds more to the values calculated for the lower part for the open hole section in FFC-1. Similar values are also presented in Aldahan et al. (1991) for the Gravberg-1 borehole in central Sweden, the Bh32012 drilling in Lake Vättern (Sundberg et al. 2016), the Outokumpu R-2500 research borehole in Finland (Kukkonen et al. 2011) and for OTN-1 well in Espoo (Kukkonen and Pentti 2021).

\section{Heat production}

The calculated heat production (A) for the crystalline section in FFC-1 using the concentrations of the radiogenic isotopes of uranium (U), thorium (Th) and potassium (K) from the spectral gamma ray log in Fig. 7 and the photo-density log is presented in Fig. 3. The average heat production is around $3.0 \mu \mathrm{W} / \mathrm{m}^{3}$. However, the heat production is considerably lower in intervals dominated by metabasite/amphibolite, around $1.5 \mu \mathrm{W} / \mathrm{m}^{3}$. In addition, the upper part down to around $2340 \mathrm{~m}$ depth also shows lower values around $2.4 \mu \mathrm{W} / \mathrm{m}^{3}$, which are influenced by the low concentration of uranium content measured over this section. It can also be seen in Fig. 7 that the concentrations of potassium and thorium differ significantly between the metabasite-amphibolite and gneiss-granite rock types, but the uranium content is quite similar. The same pattern can be seen in the spectral gamma ray log from DGE-1; see Fig. 7. The heat production in DGE-1 is higher, values reaching up to $8 \mu \mathrm{W} / \mathrm{m}^{3}$, in the open hole section down to around $3040 \mathrm{~m}$ depth. Below this depth the average heat productivity is around $3.5 \mu \mathrm{W} / \mathrm{m}^{3}$ and the values are in the same order as the ones calculated in FFC-1. This is given by the relatively higher content of uranium in the red-brown gneiss interval between 2160 and $3040 \mathrm{~m}$ in DGE-1 that contribute to a higher heat productivity in comparison to FFC-1. The average value for the entire open section in DGE-1 is $5.4 \mu \mathrm{W} / \mathrm{m}^{3}$. Heat production values within the same range as the ones calculated for FFC-1 can also be found in other wells located within the Fennoscandian Shield, such as Gravberg-1 borehole in central Sweden, Laxemar, southeast of Sweden and the Outokumpu R-2500 research borehole in Finland (Aldahan et al. 1991; Sundberg et al. 2009; Kukkonen et al. 2011).

\section{Summary of thermal data from FFC- 1 in relation to other deep boreholes}

The previously presented thermal data from FFC-1 are summarized in Table 4, as well as a comparison to data from other deep wells drilled in the upper crystalline crust within the Fennoscandian Shield. A comparison is also made with the Hunt well, which represents a similar geological setting on another Precambrian shield margin, i.e., Canadian Shield.

The thermal data acquired in FFC-1 are a valuable contribution, since there are limited number of deep wells located in the Fennoscandian Shield, as well as in the upper crystalline crust. In addition, the thermal data have been acquired from the only deep crystalline basement well in the Danish Basin. However, new temperature measurements are required to explain the different temperature gradients obtained in the well and the calculated heat flow. It seems like the temperature survey was conducted under thermal 
Table 4 Comparison of thermal data from the FFC-1 well with other deep boreholes drilled in the crystalline upper crust

\begin{tabular}{|c|c|c|c|c|c|c|}
\hline & FFC-1 & DGE-1 ${ }^{\mathrm{a}}$ & Gravberg- $1^{b}$ & $\begin{array}{l}\text { Bh32012 } \\
\text { in Lake } \\
\text { Vättern }\end{array}$ & $\begin{array}{l}\text { Outokumpu } \\
\text { R-2500 }\end{array}$ & $\begin{array}{l}\text { Hunt well, } \\
\text { Western } \\
\text { Canada }\end{array}$ \\
\hline Depth, m & 3133 & 3702 & 6957 & 1820 & 2516 & 2363 \\
\hline $\begin{array}{l}\text { Temperature, } \\
{ }^{\circ} \mathrm{C}\end{array}$ & 84 & 85 & 116 & 37 & 40 & 47 \\
\hline $\mathrm{Q}, \mathrm{mW} / \mathrm{m}^{2}$ & $51-66^{f}$ & $58^{f}$ & 50 & $35-47$ & $40-45$ & 51 \\
\hline $\begin{array}{l}\text { Gradient, }{ }^{\circ} \mathrm{C} / \\
\mathrm{km}\end{array}$ & $7-24$ & $22-24$ & $14-18$ & $15-20$ & $14-17$ & 20 \\
\hline $\mathrm{K}, \mathrm{W} /(\mathrm{m} \mathrm{K})$ & $2.4-3.6$ & $2.5-3.6$ & 3.4 & $1.8-2.8$ & $2.5-3.3$ & 2.5 \\
\hline $\mathrm{A}, \mu \mathrm{W} / \mathrm{m}^{3}$ & $3.0^{f}$ & $5.8^{f}$ & $2.0-5.0$ & $0.1^{f}$ & $1.6-5.4$ & $2.9-3.4$ \\
\hline $\begin{array}{r}\text { Dominating } \\
\text { rock types }\end{array}$ & $\begin{array}{l}\text { Gneiss, } \\
\text { amphibolite }\end{array}$ & $\begin{array}{l}\text { Gneiss, } \\
\text { amphibolite }\end{array}$ & Granite & Diorite & $\begin{array}{l}\text { Meta- } \\
\text { sediments } \\
\text { Pegmatitic } \\
\text { granite, } \\
\text { ultramafic } \\
\text { rocks }\end{array}$ & $\begin{array}{c}\text { Gneiss, granite, } \\
\text { mylonite }\end{array}$ \\
\hline
\end{tabular}

The table is partly based on information in Rosberg and Erlström (2019)

a Rosberg and Erlström (2019)

b Aldahan et al. (1991)

'S Sundberg et al. (2016)

${ }^{d}$ Kukkonen et al. (2011)

e Majorovicz et al. (2014)

${ }^{\mathrm{f}}$ Weighted average

conditions different from the pre-drilling conditions. However, the acquired values still give an indication of the general thermal regime in the well. Unfortunately, new temperature measurements will be both expensive and difficult to conduct. This is because it is a deep well and special logging equipment is required for entering the well since there is an off set in the borehole. In other words, there are only a few companies that can do the additional logging, making it even more expensive.

\section{Conclusions}

The geological investigations of FFC-1 and DGE-1 verify that the crystalline basement below the c. 2-km-thick sedimentary cover is dominated by various gneisses and mafic intrusive rocks belonging to the Sveconorwegian Province of southwestern Sweden. The density contrast between 2.6 and $3.1 \mathrm{~kg} / \mathrm{dm}^{3}$ for the two dominating rock types (gneiss and amphibolite) provides favourable conditions for creating seismic reflectors, which is also verified by the thick amphibolite in gneiss-dominated surroundings as in the bottom of the FFC-1 borehole.

The upper c. $400 \mathrm{~m}$ of the basement in FFC-1 is severely fractured and water-bearing which disqualified the continuation of the planned use of percussion air drilling and conventional rotary drilling was performed for the rest of the borehole. The evaluation of the conventional rotary drillings in FFC-1 and DGE-1 concluded high drill bit consumption and low ROPs in both boreholes. The average bit life was $62 \mathrm{~m}$ and $68 \mathrm{~m}$ in the two wells with an average ROP between 2 and $4 \mathrm{~m} / \mathrm{h}$ without any preferences regarding bit-type (PDC or TCI). The geological investigations show a comparable composition of 
the crystalline basement which is interpreted to not significantly affect any difference in drilling performance between the two sites.

The bottomhole temperature in the FFC- 1 borehole is $84.1{ }^{\circ} \mathrm{C}$. In the upper part of the crystalline basement $2150-2610 \mathrm{~m}$, the temperature gradient of $24^{\circ} \mathrm{C} / \mathrm{km}$ and calculated heat flow of $66 \mathrm{~mW} / \mathrm{m}^{2}$ are considerably higher than reported from other deep wells in the Fennoscandian basement. The corresponding values for the deeper parts of the FFC-1 well are $17^{\circ} \mathrm{C} / \mathrm{km}$ and $51 \mathrm{~mW} / \mathrm{m}^{2}$, which are more like the values reported from other deep wells in the Fennoscandian basement. However, inflow of colder formation fluid from hydraulically active fractures strongly influences the temperature conditions in the well below $2562 \mathrm{~m}$. New measurements under equilibrated temperature conditions are required to evaluate how much the low gradient is influenced by the hydraulically active fractures between 2562 and $2695 \mathrm{~m}$.

The average heat production is $3.0 \mu \mathrm{W} / \mathrm{m}^{3}$ in FFC-1 and generally lower values are observed for intervals dominated by amphibolite/metabasite, around $1.5 \mu \mathrm{W} / \mathrm{m}^{3}$. The rocks in FFC-1 are overall depleted in uranium and thorium in comparison to the rocks in the DGE-1 borehole. The heat productivity in DGE-1 is, overall, higher with an average of $5.8 \mu \mathrm{W} / \mathrm{m}^{3}$.

The spatial distribution of fractures has successfully been mapped using borehole imaging logs. The evaluation of the data and calculation of the linear fracture frequency for three main borehole intervals including the fractured zone $(2562-2695 \mathrm{~m}$ ) and the interval above (2450-2522 m) and below (2695-3106 m) show a dominance of N-S oriented open fractures, a fracture frequency varying between 0.85 and $2.49 \mathrm{frac} / \mathrm{m}$ and a fracture volumetric density between 1.68 and $3.39 \mathrm{~m}^{2} / \mathrm{m}^{3}$. Scattered thinner intervals with higher values are also noted, but overall these data correlate to what is noted for similar, though scarce reference data from other deep wells in crystalline rocks.

In sum, the FFC-1 and DGE-1 boreholes have provided insight and new empirical data on the concealed crystalline basement in the Fennoscandian Shield Border Zone that previously only had been assessed by assumptions and modelling. The outcome of the drilling operation has also provided insight regarding the drilling performance of the basement and statistical data on various drill bits used.

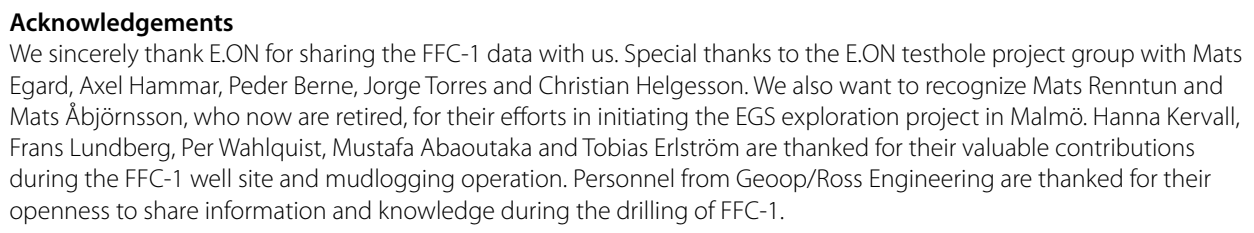
Egard, Axel Hammar, Peder Berne, Jorge Torres and Christian Helgesson. We also want to recognize Mats Renntun and Mats Åbjörnsson, who now are retired, for their efforts in initiating the EGS exploration project in Malmö. Hanna Kervall, Frans Lundberg, Per Wahlquist, Mustafa Abaoutaka and Tobias Erlström are thanked for their valuable contributions during the FFC-1 well site and mudlogging operation. Personnel from Geoop/Ross Engineering are thanked for their openness to share information and knowledge during the drilling of FFC-1.

\section{Authors' contributions}

Both authors contributed to the synopsis, background, and method descriptions. ME compiled and interpreted the geological and geophysical data. JER compiled and evaluated the drilling and the thermal data. Both authors contributed to the discussion, conclusions, and illustrations. Both authors read and approved the final manuscript.

\section{Funding}

Open access funding provided by Lund University. The used background data on the FFC-1 well come primarily from the E.ON testhole project, that was partly funded by the Swedish Energy Agency (Project No: 49110-1). The performed appraisal by the authors and complementary analyses have been funded by the Geological Survey of Sweden and the departments of Engineering Geology and Geology at Lund University.

\section{Availability of data and materials}

The logging data, cuttings material and well reports used for this study are available at E.ON Malmö, the Geological Survey of Sweden and at the Department of Engineering Geology at Lund University. The FFC-1 well is presently accessible and located in a locked concrete cellar, even though there is an off set in the well at $2263 \mathrm{~m}$, which requires special logging tool strings to pass. 


\section{Declarations}

Competing interests

The authors declare that they have no competing interests.

\section{Author details}

${ }^{1}$ Engineering Geology, Faculty of Engineering, Lund University, Box 118, 22100 Lund, Sweden. ${ }^{2}$ Geological Survey of Sweden, Kiliansgatan 10, 22350 Lund, Sweden. ' Department of Geology, Lund University, Sölvegatan 12, 22362 Lund, Sweden.

Received: 31 May 2021 Accepted: 28 July 2021

Published online: 06 August 2021

\section{References}

Aldahan AA, Castañ J, Collini B, Gorody T, Juhlin C, Sandstedt H. Scientific summary report of the deep gas drilling project in the Siljan Ring Impact structure. Vattenfall Rep. p. 1-257. 1991.

Allis R, Moore J, Davatzes N, Gwynn M, Hardwick C, Kirby S, McLennan J, Pankow, K, Potter S, Simmons, S. EGS concept testing and development at the Milford, Utah FORGE Site. In: proceedings, 41st Workshop on geothermal reservoir engineering Stanford University, Stanford, California, February 22-24, 2016 SGP-TR-209. p. 13. 2016.

Andersson O. Deep drilling KLX 02-drilling and documentation of a $1700 \mathrm{~m}$ deep borehole at Laxemar, Sweden. SKB Rep TR 94-19. p. 46. 1994.

Armstead HCH, Tester JW. Heat mining. London: E. and F. N. Spon; 1987.

Arshavskaya NI, Galdin NE, Karus EW, Kuznetsov OL, Lubimova EA, Milanovsky SY, Nartikoev VD, Semashko SA, Smirnova EV. Geothermic investigations. In: Kozlovsky YA, editor. The superdeep well of the Kola Peninsula. Berlin: Springer; 1984. p. 387-93.

Badulescu C, Ciuperca C. FFC-1 data interpretation report IAES weatherford report, internal project report. 2021.

Balling N. Heat flow and lithospheric temperature along the northern segment of the European Geotraverse, In: Freeman R, Mueller St, editors. In: proceedings of the 6th workshop of the European Geotraverse (EGT) Project, European Science Foundation, Strasbourg. 1990; 405-16.

Balling N. Heat flow and thermal structure of the lithosphere across the Baltic Shield and northern Tornquist Zone. Tectonophysics. 1995;244:13-50.

Bergertat F, Angelier J, Andreasson P-G. Evolution of paleostress fields and deformation of the Tornquist Zone in Scania (Sweden) during Permo-Mesozoic and Cenozoic times. Tectonophysics. 2007;444:93-110.

Brown DW. Hot dry rock geothermal energy: important lessons from Fenton Hill. In: proceedings 34th workshop on geothermal reservoir engineering, SGP-TR-187. Stanford, CA; 2009. p. 139-42.

Bücker C, Rybach L. A simple method to determine heat production from gamma-ray logs. Mar Pet Geol. 1996;13:373-5.

Cardoe J, Nygaard G, Lane C, Saarno T, Bird M. Oil and gas drill bit technology and drilling application in engineering saves 77 drilling days on the World's deepest engineered geothermal systems EGS wells. SPE/IADC-204121-MS. 2021.

Chapman DS, Furlong KP. Thermal state of the continental lower crust. In: Arculus DM, Kay KW, editors. Continental lower crust. Amsterdam: Elsevier; 1992. p. 179-99.

Ciuperca C-L, Camil B, Erlström M, Hammar A, Egard, M. An integrated formation evaluation approach evaluated the basement temperature anomaly. EAGE 82nd conference and exhibition, amsterdam, extended abstract: p. 4. 2021.

DONG. Final testing report FFC-1, geothermal project Malmö, E.ON project report. 2003.

DONG. Final well report FFC-1, Geothermal project Malmö, E.ON project report. 2006.

E.ON. End of well report-air hammer FFC 1 20201221, internal project report. 2021.

Emmermann R, Lauterjung J. The German continental deep drilling program KTB: overview and major results. J Geophys Res. 1997;102:18179-201.

Energy and Geoscience Institute at the University of Utah. Utah FORGE: well 56-32 drilling data and logs. 2021. https:// doi.org/10.15121/1777170.

Erlström M. Chapter 24: carboniferous-neogene tectonic evolution of the Fennoscandian transition zone, southern Sweden. In: Stephens M-B, Weihed JB, editors. Sweden lithotectonic framework, tectonic evolution and mineral resources, vol. 50. London: Geological Society Memoir; 2020. p. 603-20.

Erlström M, Deeks N, Sivhed U, Thomas S. Structure and evolution of the Tornquist Zone and adjacent sedimentary basins in Scania and the southern Baltic Sea area. Tectonophysics. 1997;271:191-215.

Erlström M, Sivhed U, Wikman H, Kornfält KA. Beskrivning till berggrundskartorna 2D Tomelilla NV, NO, SV, SO, 2E Simrishamn NV, NO, 1E Örnahusen NV. Sveriges geologiska undersökning; Af 212-214:1-141. 2004 (in Swedish with an English summary).

Erlström M, Boldreel LO, Lindström S, Kristensen L, Mathiesen A, Andersen MS, Nielsen LH. Stratigraphy and geothermal assessment of Mesozoic sandstone reservoirs in the Øresund Basin-exemplified by well data and seismic profiles. Bull Geol Soc Den. 2018;66:123-49.

EUGENO-s Working Group. Crustal structure and tectonic evolution of the transition between the Baltic Shield and the north German Caledonides. Tectonophysics. 1998;150:253-348.

Garabetian T (2019) Report on competitiveness of the geothermal industry. Tech Rep, European technology and innovation platform on deep geothermal (ETIP-DG). http://www.etip-dg.eu/front/wp-content/uploads/D4.6-Report-onCompetitiveness.pdf. Accessed 10 May 2021.

Halling J. Inventering av sprickmineraliseringar i en del av Sorgenfrei-Tornquistzonen, Dalby stenbrott, Skåne. Master of Science thesis Department of Geology, Lund University. 2015; 448:1-36 (in Swedish). 
Hammar A, Erlström M, Heikkinen P, Juhlin C, Malin P. Malmö EGS site basement-reflection seismic reinterpretation and drill confirmation. Abstract, geothermal resources council annual meeting and expo, San Diego. 2021.

Howard-Orchard D. Final well report Lund DGE\#1 deep geothermal energy project, Lunds Energi, technical report. 2003. IADC. IADC drilling manual eBook version (V.11). International association of drilling contractors. 2000.

Jiang G, Tang X, Rao S, Gao P, Zhang L, Zhao P, Hu S. High-quality heat flow determination from the crystalline basement of south-east margin of north China Craton. J Asian Earth Sci. 2016;1 18:1-10.

Juhlin C, Wallroth T, Smellie J, Leijon B, Eliasson T, Ljunggren C, Beswick J. The very deep hole concept-geoscientific appraisal of conditions at great depth. Swedish Nuclear Waste Programme Technical Report SKB-TR-98-05. p. 128.

Klitzsch N, Ahrensmeier L. Thermal matrix properties measured on cuttings from the Malmö well. Brief report about test measurements on 5 cuttings. RWTH Aachen Univ Rep. 2021.

Kukkonen IT, editor. Outokumpu deep drilling project 2003-2010. Geological Survey of Finland, Special paper 51. 2011.

Kukkonen IT, Pentti M. St1 deep heat project: geothermal energy to the district heating network in Espoo. IOP Conf Ser Earth Environ Sci. 2021;703: 012035.

Kukkonen IT, Rath V, Kivekäs L, Šafanda J, Cermak V. Geothermal studies of the Outokumpu Deep Drill Hole, Finland: vertical variation in heat flow and paleoclimatic implications. Phys Earth Planet Inter. 2011;188:9-25.

Leary P, Malin P, Saarno T, Kukkonen I. Prospects for assessing enhanced geothermal system (EGS) basement rock flow stimulation by wellbore temperature data. Energies. 2017;10(12):1-33. https://doi.org/10.3390/en10121979.

Ledingham P, Cotton L, Law R (2019) The united downs deep geothermal power project. In: proceedings, 44th workshop on geothermal reservoir engineering Stanford University, Stanford, California, February 11-13, 2019 SGP-TR-214, p. 11.

Liboriussen J, Ashton P, Tygesen T. The tectonic evolution of the Fennoscandian Border Zone. Tectonophysics. 1987:137:21-9.

Lorenz H, Rosberg J-E, Juhlin C, Bjelm L, Almqvist B, Berthet T, Conze T, Gee D, Klonowska I, Pascal C, Pedersen K, Roberts $\mathrm{N}$, Tsang C-F. COSC-1-drilling of a subduction-related allochthon in the Palaeozoic Caledonide orogen of Scandinavia. Sci Dril. 2015;19:1-11.

Majorowicz J, Chan J, Crowell J, Gosnold W, Heaman LM, Kück J, Nieuwenhuis G, Schmitt DR, Unsworth M, Walsh N, Weiders $\mathrm{S}$. The first deep heat flow determination in crystalline basement rocks beneath the Western Canadian Sedimentary Basin. Geophys J Int. 2014;197:731-47.

Malin P, Saarno T, Kwiatek G, Kukkonen I, Leary P, Heikkinen P. Six Kilometers to Heat: Drilling, Characterizing \& Stimulating the OTN-3 Well in Finland. In: Proceedings: World Geothermal Congress. Reykjavik, Iceland; 2021.

Meet. Deliverable D3.2. 1D/2D DFN models of borehole fractures and hydraulic circulation simulations. H2020 Grant Agreement No 792037. 2019. https://www.meet-h2020.com/wp-content/uploads/2020/07/MEET_Deliverable_ D3.2 25042019 VF.pdf. Accessed 15 Apr 2021.

Morad S, El-Gahli MAK, Caja MA, Sirat M, Al-Ramadan K, Mansurbeg H. Hydrothermal alteration of plagioclase in granitic rocks of proterozoic basement SE Sweden. Geol J. 2010. https://doi.org/10.1002/gj1078.

Norling E, Wikman H. Beskrivning till berggrundskartan Höganäs NO/Helsingborg NV. Sveriges Geologiska Undersökning Af. 1990;129:1-123 (in Swedish with an English summary).

Plümper O, Putnis A. The complex hydrothermal history of granitic rocks: multiple feldspar replacement reactions under subsolidus conditions. J Petrol. 2009;50:967-87.

La Pointe P, Fox A, Hermanson J, Öhman J (2008) Geological discrete fracture network model for the Laxemar site-site descriptive modelling SDM-Site Laxemar. SKB report R-08-55. p. 260.

Rogers S, Elmo D, Webb G, Catalan A. Volumetric fracture intensity measurement for improved rock mass characterisation and fragmentation assessment in block caving operations. Rock Mech Rock Eng. 2015;48:633-49.

Rosberg J-E, Erlström M. Evaluation of the Lund deep geothermal exploration project in the Romeleåsen fault zone, south Sweden: a case study. Geotherm Energy. 2019;7:10.

Sivhed U, Wikman H, Erlström M. Beskrivning till berggrundskartorna 1C Trelleborg NV, NO, 2C Malmö SV, SO, NV, NO. Sveriges geologiska Undersökning. Af 191-194, 196, 198:1-143. 1999. (in Swedish with an English summary).

SKB (2009) Site description of Laxemar at completion of the site investigation phase SDM-site Laxemar. SKB Rep TR 09-01. p. 637.

Stephens MB, Wahlgren C-H. Chapter 15: polyphase continental crust eastern segment, sveconorwegian orogeny. In: Stephens M-B, Weihed JB, editors. Sweden lithotectonic framework, tectonic evolution and mineral resources, vol. 50. London: Geological Society Memoir; 2020. p. 351-96.

Sundberg J, Back P-E, Ländell M, Sundberg A (2009) Modelling of temperature in deep boreholes and evaluation of geothermal heat flow at Forsmark and Laxemar. SKB Techn Rep. TR-09-14. 2009; p. 87.

Sundberg J, Näslund J-O, Claesson Liljedahl L, Wrafter J, O'Regan M, Jakobsson M, Preto, P, Larson S-Å. Thermal data for paleoclimate calculations from boreholes at Lake Vättern. SKB Rep. P-16-03. 2016; p. 160.

Teale R. The concept of specific energy in rock drilling. Int J Rock Mech Min Sci. 1965;2:57-73.

Tester JW, Anderson BJ, Batchelor AS, Blackwell DD, DiPippo R, Drake EM, Garnish J, Livesay B, Moore MC, Nichols K, Petty S, Toksoz MN, Veatch RW. The Future of Geothermal Energy Impact of Enhanced Geothermal Systems (EGS) on the United States in the 21st Century, Massachusetts Institute of Technology; 2006. https://www1.eere.energy.gov/ geothermal/pdfs/future_geo_energy.pdf. Accessed 5 Apr 2021.

Think Geoenergy. Drilling Finland's deepest well on record - the geothermal well at Otanemi, Richter A. 2019. https:// www.thinkgeoenergy.com/drilling-finlands-deepest-well-on-record-the-geothermal-well-at-otaniemi/. Accessed 26 April 2021.

Thybo H. A seismic model along the EGT profile - from the North German Basin into the Baltic Shield. In: Proceedings of the 5th Study Centre on the European Geotraverse Project. Strasbourg: ESF; 1990. p. 99-108.

Ulmius J, Möller C, Page L, Johansson L, Ganerod M. The eastern boundary of Sveconorwegian reworking in the Baltic Shield defined by 40Ar/39Ar geochronology across the southernmost Sveconorwegian Province. Precambr Res. 2018;307:201-17.

Wikman H, Bergström J, Sivhed U. Beskrivning till berggrundskartan Helsingborg SO. Sveriges Geologiska Undersökning Af. 1993;180:1-114 (in Swedish with an English summary). 
Wollenberg HA, Smith AR. Radiogenic heat production of crustal rocks: an assessment based on geochemical data. Geophys Res Lett. 1987;16:295-8.

Zimmermann G, Alexander K, Burkhardt H. Hydraulic pathways in the crystalline rock in KTB. Geophys J Int. 2000;142:4-14.

\section{Publisher's Note}

Springer Nature remains neutral with regard to jurisdictional claims in published maps and institutional affiliations.

Submit your manuscript to a SpringerOpen ${ }^{0}$ journal and benefit from:

- Convenient online submission

- Rigorous peer review

- Open access: articles freely available online

- High visibility within the field

- Retaining the copyright to your article

Submit your next manuscript at $>$ springeropen.com 